Pamiętnik Literacki 2017, 1, s. 206-218
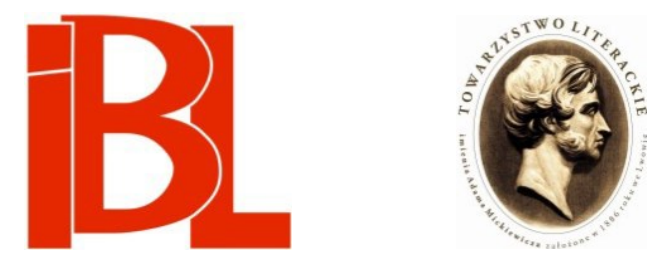

\title{
Dyspersje strukturalizmu
}

Magdalena Rembowska-Płuciennik

Rec. : Emilia Januszek, Dyskurs teoretycznoliteracki

Janusza Sławińskiego. (Kraków 2012).

Strukturalizm w Europie Środkowej i Wschodniej.

Wizje i rewizje. Pod. redakcją: D. Ulickiej i W.

Boleckiego. Warszawa 2012.

Piotr Gierowski, Struktury historii. O czeskim projekcie dziejów literatury na tle recepcji praskiego strukturalizmu w Polsce. (Kraków 2013). 
MAGDALENA REMBOWSKA-PŁUCIENNIK Instytut Badań Literackich PAN, Warszawa

\section{DYSPERSJE STRUKTURALIZMU}

Emilia Janu szek, DYSKURS TEORETYCZNOLITERACKI JANUSZA SŁAWIŃSKIEGO. (Recenzent: Ryszard Nycz). (Kraków 2012). Wydawnictwo Uniwersytetu Jagiellońskiego, ss. 236.

STRUKTURALIZM W EUROPIE ŚRODKOWEJ I WSCHODNIEJ. WIZJE I REWIZJE. Pod redakcja Danuty Ulickiej i Włodzimierza Boleckiego. (Recenzenci: Jarosław Płuciennik, Jolanta Sujecka. Indeks: Krystyna Petryk). Warszawa 2012. Fundacja Akademia Humanistyczna / Instytut Badań Literackich PAN - Wydawnictwo, ss. 522. „Z Dziejów Form Artystycznych w Literaturze Polskiej”. Komitet Redakcyjny: Janusz Sławiński (red. naczelny), Edward Balcerzan, Kazimierz Bartoszyński. Tom 92.

P i o t r G i e r o w s k i, STRUKTURY HISTORII. O CZESKIM PROJEKCIE DZIEJÓW LITERATURY NA TLE RECEPCJI PRASKIEGO STRUKTURALIZMU W POLSCE. (Recenzent: Maria Dąbrowska-Partyka). (Kraków 2013). Wydawnictwo Uniwersytetu Jagiellońskiego, ss. 234.

W latach 2012-2013 ukazały się trzy nowe publikacje zaświadczające o ożywionym zainteresowaniu polskim wariantem strukturalizmu - różnymi jego nurtami, środowiskami i etapami rozwoju. Zawarte w tych książkach analizy nie przyjmują formy zamknięcia dyskusji nad przedmiotem ostatecznie poznanym i mającym wartość jedynie historyczną. Choć dla najmłodszego pokolenia badaczy zgłębiających dzieje strukturalizmu nie jest on już najbliższą i naturalną tradycją naukową, wobec której należy uzasadnić własne wybory metodologiczne, to kierunek ten nadal okazuje się intrygujący i pobudzający do refleksji. Nie bez znaczenia pozostaje chęć wyeliminowania częstego błędu perspektywy badawczej, który sprowadza strukturalizm do jednolitej matrycy lub też zawęża go do jednej z lokalnych jego wersji. Długoletnie niedostrzeganie (zwłaszcza w USA czy w Europie Zachodniej) źródła nowoczesnego literaturoznawstwa w pomysłach zrodzonych także na przeciwległym krańcu kontynentu zapoczątkowało chęć odtworzenia cyrkulacji idei, kierunków osmozy myśli i peregrynacji nie tylko uczonych, ale i koncepcji formalno-strukturalistycznych czy protostrukturalistycznych.

Wzmożona mobilność przedstawicieli nowego kierunku nie do końca tłumaczy dobre przyjęcie strukturalizmu w różnych kręgach kulturowych, problemem równie ciekawym stało się więc odtworzenie skomplikowanych relacji między lokalna gotowością do akceptacji nowych tendencji w poszczególnych „miastach i państwach” strukturalizmu a rzeczywistą inspiracją zewnętrzną. Zważywszy, że inspiracja ta niekiedy przyjmowała postać chronologicznie ujednoliconego konglomeratu idei rosyjsko-czesko-francuskich, nie sposób nie odnieść wrażenia, iż w kolejnych odsłonach recepcji strukturalizmu to właśnie owe przemieszczenia, swoiste „uskoki tektoniczne” pomiędzy warstwami teorii stają się szczególnie atrakcyjne dla współczesnych eksploracji. Strukturalizm pociaga, być może, właśnie dlatego, że dystans czasowy, jaki dzieli nas od apogeum jego produktywności, wydobywa heterogeniczność zjawiska. Nieuprzedzonemu oku ukazuje ono w swoich własnych pokładach istnienie wielu aktualnych do dzisiaj idei lub problemów dopiero domagających się podjęcia - naturalnie w ramach innych metod badawczych. Ten zaskakujący wewnętrzny potencjał rozwojowy, swoista energia uwalniana do teraz w różnych sferach badań literackich i kulturowych to coś więcej niż możliwość aktualizowania zasygnalizowanych niegdyś problemów. To nadal występujące promieniowanie, oddziałujące na języki o wiele późniejsze, jest bardzo ciekawym, niekiedy podskórnym wątkiem trzech książek, które będą tu omawiane.

Praca Emilii Januszek Dyskurs teoretycznoliteracki Janusza Sławińskiego ma najwęższy zakres tematyczny; to wnikliwe studium stylistyki i poetyki tekstów naukowych, w których 
autorka poszukuje osobowej sygnatury podmiotowości wybitnego humanisty ${ }^{1}$. Przygląda się strategiom dyskursywnym Janusza Sławińskiego: uczonego-instytucji; badacza nierzadko utożsamianego ze strukturalizmem warszawskim, ale i nie do końca mieszczącego się w rygorystycznie wyznaczanych ramach kierunku naukowego. Jednym $z$ impulsów dla nowej fali recepcji jest więc chęć podsumowania dorobku najwybitniejszych reprezentantów powojennej teorii literatury ${ }^{2}$, którzy osiagnęli status klasyków humanistyki polskiej, równocześnie stając się obiektami analizy dokonywanej narzędziami poststrukturalistycznymi: tropiącej biograficzne uwarunkowania, idiosynkrazje, jawne i skrywane własności idiolektu.

Punktem wyjścia dla autorki jest powracająca już w omówieniach dorobku Sławińskiego charakterystyczna rozbieżność klasyfikacji jego wyborów i koncepcji teoretycznych. Sławiński bywa bowiem postrzegany jako ikona swego pokolenia oraz prawodawca nowych reguł języka i życia naukowego w Polsce, twórca teorii i jednocześnie jej najwybitniejszy praktyk. Ale przypisuje mu się zarazem - intencjonalne lub nie - doprowadzenie jej do punktów granicznych i miejsc przesilenia, predylekcję do ujawniania tych problemów, które, steoretyzowane w ramach innych języków, okazywały się impulsem do poststrukturalistycznej wolty ${ }^{3}$. Sławiński może być więc widziany jako papież strukturalizmu i pierwszy polski poststrukturalista ${ }^{4}$, lecz żaden $z$ tych portretów nie jest lustrzanym jego odbiciem. Januszek pozornie unika tej dychotomii, odrzucając (przynajmniej na poziomie deklaracji) wytłumaczenie dwoistości postaw badawczych Sławińskiego naturalną ewolucją jego koncepcji teoretycznych. Cel autorki stanowi charakterystyka współwystępowania dwóch stylów myślenia teoretycznego i praktyk wysłowienia istniejących (z różnym natężeniem) na wszystkich, jej zdaniem, poziomach i etapach twórczej pracy uczonego. Januszek pokazuje więc, jak w jednym tekście naukowym, w obrębie jednej uprawianej formy wypowiedzi, w tym samym okresie działalności może dochodzić do konfrontacji opozycyjnych postaw i dyskursów je reprezentujących. Sławińskiego doktrynera, rygorystycznego stróża profesjonalnego języka obiektywizmu i naukowości, żyjącego w autonomicznym świecie tekstu, wydzielonym autorytarnym gestem prawodawcy i utwierdzonym moca języka Wiedzy-Władzy, jak określa autorka styl najbardziej charakterystycznych, kanonicznych prac badacza ${ }^{5}$. I Sławińskiego z podejrzliwością traktującego ideę teorii jako monolitycznego konstruktu, badacza uznającego wielogłosowość metodologiczną swojej dyscypliny za przejaw jej żywotności; ironisty

1 Można wobec tego również skojarzyć tę książkę z impulsem antropologii literaturoznawstwa, jaka zaproponowała D. Uli c k a (Literaturoznawcze dyskursy możliwe. Studia z dziejów nowoczesnej teorii literatury $w$ Europie Środkowo-Wschodniej. Kraków 2007).

2 Jedną $z$ form recepcji są jubileuszowe tomy dedykowane J. Sławińskiemu (Dzieła, języki, tradycje. Red. W. B ole cki, R. Ny c z. Warszawa 2006), M. Głowińskiemu (Poetyka-polityka-retoryka. Red. W. B ole c ki, R. Ny c z. Warszawa 2006), E. Balcerzanowi (Od tematu do rematu. Przechadzki z Balcerzanem. Księga jubileuszowa z okazji 70 rocznicy urodzin Profesora Edwarda Balcerzana. Red. T. Mizerki ewi cz, A. Stankows ka. Poznań 2007) czy numery tematyczne czasopism, np. „Tekstów Drugich” - dedykowanych J. Sławińskiemu (1994, nr 4), M. Głowińskiemu (1994, nr 5/6), Z. Łapińskiemu (2000, nr 5).

3 Zob. A. Skr e n d o, „Generał czytania” - Janusz Sławiński i sztuka interpretacji. W: Poezja modernizmu. Interpretacje. Kraków 2005, s. 297-303.

4 Zob. W. B ole c ki, PPP: Pierwszy Polski Poststrukturalista. „Teksty Drugie” 1997, nr 4. Jak uważa autor - znamienną cechą praktyki naukowej Sławińskiego było wskazywanie problemów, nie ich rozwiązywanie; kwestionowanie własnej teorii, nie zaś czynienie z niej samoograniczającej zwartej doktryny.

$5 \quad$ O swoich dwóch naturach mówił sam J. Sławińs ki (np. Małe wyznanie autora. W: Prace wybrane. T. 3: Teksty i teksty. Red. W. Bol e c ki. Kraków 2000). Jako czynnik dynamizujący koncepcje badacza rozważa je także J. Ma d e j ski (Biografia struktury - struktura biografii. W zb.: Dzieła, języki, tradycje). 
tropiącego figuratywność własnego języka i świadomego, że pozatekstowa obecność świata czytelnika wpływa na kształt badań, ale i - co bardziej dla niego niepokojące - na kształt ich przedmiotu. Tę swoistą przekorę naukową Sławińskiego - a może umiejętność reewaluacji założeń teoretycznych własnych działań lub autorefleksję? - opisuje Januszek wnikliwie i interesująco.

W części I, Teoria literatury jako prawodawstwo, autorka rekonstruuje właściwości językowo-tekstowe znormatyzowanego stylu profesjonalnego, jaki wypracował Sławiński. Styl ten posłużył do nazwania nowych zadań literaturoznawstwa (lub szerzej: humanistyki) i do stworzenia jego podstaw teoretyczno-instytucjonalno-dydaktycznych. Stanowił propozycję nowego słownika pojęciowego i zbioru regulacji, jakim zostały poddane pisanie o literaturze i czytanie literatury. Do najwyraźniejszych cech dyskursu Sławińskiego autorka zalicza systemowość - konsekwentnie wyrażaną i realizowaną w różnych sferach aktywności naukowej wizję całościowego, koherentnego ujęcia własnej dyscypliny naukowej. Teksty badacza ujawniają identyczna prawodawczą intencję wskazywania immanentnego porządku w relacjach między jednostkami poddanymi analizie: czy to na poziomie opisu języka literackiego, konkretnego dzieła czy też refleksji nad własnymi narzędziami teoretycznymi. Potrzebie zbudowania kompletnej wiedzy literaturoznawczej odpowiadał projekt poetyki strukturalistycznej mającej pełnić funkcję metodologicznego zwornika dyscypliny i gwaranta stabilności jej przedmiotu badań, a także ochrony przed niepożądanym zróżnicowaniem języków teoretycznych. Na poziomie języka teoretycznego systemowość Sławińskiego uwidacznia się też w preferowanych przez niego sposobach konstruowania wywodu i argumentowania. Autorka analizuje więc „tektoniczną wyobraźnię” badacza, najczęściej opisującego omawiane przez siebie zjawiska poprzez wyobrażenie bytu o konstrukcji warstwowej. Jego poznanie odbywa się dzięki ruchowi wznoszącemu z poziomu niższych warstw ku spójnej, funkcjonalnej całości. Procedurę równie istotną stanowi formułowanie jasnych, nierzadko kategorycznych reguł rządzących tym procesem - stąd w języku uczonego tendencja do wyliczeń, wyrazistych podziałów, konstytuowanie znaczących opozycji i nierzadko apodyktyczny ton.

Figura opozycji u Sławińskiego jest dla Januszek zarazem ważnym zabiegiem konstruującym jej tok dowodowy - właśnie owo wewnętrzne napięcie między antynomicznymi poglądami, postawami badawczymi, ideami czyni ona rozpoznawczym znakiem jego myśli teoretycznej oraz osobnej pozycji w gronie pokolenia. Owo „bycie pomiędzy” - jako strategiczna praktyka anarchistycznego prawodawcy i eklektycznego systemotwórcy - zagwarantowało Sławińskiemu, zdaniem autorki, możliwość efektywnego wpływu na wszystkie uprawiane przez niego subdziedziny literaturoznawcze. Januszek rekonstruuje stopniowe zanikanie dogmatyzmu i kategoryczności wypowiedzi Sławińskiego, prezentuje teksty ujawniające delikatne, acz znaczące zmiany w poprzednio głoszonych sądach, wskazuje narodziny idei, które stoją w wyraźnej opozycji do sformułowań wcześniejszych ${ }^{6}$. Omawia zarówno najważniejsze rozprawy naukowe badacza, jak i jego szkice krytycznoliterackie czy różnogatunkowe wypowiedzi mniej sformalizowane. Nie akcentuje przy tym jednak faktu, że przeprowadzane przez Sławińskiego „demontowanie” teorii odbywa się najczęściej w tekstach o znacznie osłabionej mocy retorycznej gatunku - w obrębie notatek (Bez przydziału), szkiców, felietonów. Odtworzenie przemian w poglądach naukowca polega na tym, by wydobyć $z$ jego prac problemy, które, stopniowo nabierając znaczenia, każdorazowo doprowadzały do rozpoznania słabszych punktów jego teorii oraz zmuszały do ponownego przemyślenia czy nawet zmodyfikowania jej podstaw.

6 Na temat celowego zarzucania problemów metodologicznych dostrzeganych przez samych strukturalistów jako pewnej strategii pisze M. Saganiak w książce Strukturalizm. Pytania otwarte (Warszawa 2016). 
Część II książki, Praktykowanie teorii, poświęcona jest rozprawom krytycznoliterackim i interpretacyjnym badacza: zasadom analizy języka artystycznego, metodom projektowania wewnętrznych relacji w rozpatrywanych utworach i między ich grupami, doborowi materiału porównawczego dla prezentowanych zjawisk, propozycjom terminologicznym i uprzywilejowanym gatunkom wypowiedzi. W sposób szczególny dochodzi tu do głosu ta cecha myślenia i pisania Sławińskiego, którą autorka określa jako antysystemowość, osłabianie scjentyzmu i ujawnianie indywidualności twórczej. Precyzja kompozycji, metaforyczność języka, predylekcja do posługiwania się w toku wywodu formą exemplum czy dynamizującym argumentację obrazem są wyznacznikami stopniowego oscylowania w kierunku literackości przekazu naukowego, w którym w pełni może się zaprezentować wyjątkowość głosu naukowca.

Niechciane przez autorkę pojęcie ewolucji powraca więc nieuchronnie. Wielokrotnie zastrzega ona jednak, że złożoność postawy naukowej Sławińskiego nie jest efektem tak prostej wizji rozwoju. Tymczasem liczne cytaty $z$ jego prac i równie liczne określenia przez samą Januszek stosowane odsyłają wprost do zmienności w czasie - lub wręcz do ewolucji właśnie! - jako do przyczyny niuansowania przez Sławińskiego dawniejszych rozstrzygnięć. Pomysł, by ten tryb autorefleksji zastąpić modelem opisu uznającego współistnienie rozbieżnych wątków za spiritus movens naukowej twórczości badacza, wydaje się więc tyleż błyskotliwy, co kłopotliwy, a niekiedy karkołomny. Owszem, podkreśla się wówczas niepoślednią zdolność bohatera książki do przenikliwego, autokrytycznego i wieloperspektywicznego oglądu różnych zjawisk teoretycznoliterackich, ale pomija się dość beztrosko fakt, że lektura wczesnych prac naukowca odbywa się z perspektywy wniosków i samoocen zawartych w pracach o dziesięciolecia późniejszych. Tym bardziej że autorka nierzadko precyzyjnie wskazuje ważne wydarzenia, które rzutowały na sposób myślenia i pisania Sławińskiego (np. udział w słynnych międzynarodowych konferencjach teoretycznych organizowanych przez M. R. Mayenową czy też objęcie funkcji redaktora naczelnego „Tekstów”). Sytuacyjne umocowanie jego koncepcji teoretycznych i strategii twórczych - często rodzących się w świadomości bliskiego zetknięcia $z$ kontrpropozycjami teoretycznymi - również immanentnie bardziej sprzyja, niż przeszkadza uhistorycznionemu opisowi drogi naukowej badacza. Widać wówczas, że na jego myśl miały wpływ zmiany w obrębie całej humanistyki drugiej połowy XX wieku oraz że chciał i umiał on na te zmiany plastycznie reagować - nie z pozycji ortodoksyjnych, ale dzięki samokrytycyzmowi oraz towarzyszącym mu strategiom autorefleksji: ironii, zdystansowaniu, a nawet humorowi. Januszek wielokrotnie wspomina, że pewne cechy jego myślenia i pisania o literaturze pojawiają się częściej we wczesnej fazie drogi naukowej, ku innym ciąży dorobek fazy późniejszej.

Kompozycja książki też potwierdza niemożność wyeliminowania rozwoju chronologicznego znamiennych dla dyskursu Sławińskiego cech: autorka analizuje - stopniowo przecież narastająca - tendencję do personalizowania wypowiedzi czy do jej autobiografizującego nachylenia, niemożliwą do zaistnienia kilkadziesiąt lat wcześniej. Nadmierne akcentowanie komplementarności rozbieżnych metodologicznych dążeń i rozstrzygnięć naukowych stwarza wrażenie usilnego szukania przez Januszek własnego, „innego” pomysłu na opis dorobku Sławińskiego, a przecież podejmuje ona istniejący już od dawna trop interpretacyjny. Nie ulega jednak wątpliwości, że praca analityczna przez nią przeprowadzona jest drobiazgowa, rzetelna i bardzo ciekawie wskazuje osobnicze cechy napędzające wewnętrzna „sporność” (by użyć pojęcia użytego przez badacza ${ }^{7}$ ) jego literaturoznawczego pisarstwa.

Januszek rozpoznaje również istotne dla twórczości naukowej Sławińskiego strategie perswazyjne, dzięki którym stał się on uosobieniem nowego języka nauki o literaturze obiektywistycznego, scjentystycznego, nierzadko oskarżanego o apodyktyczność. Autorka 
świetnie pokazuje, jak to, co w rzeczywistości idiolektalne, służy kreowaniu w jego tekstach neutralności i wspomaganiu języka rzekomo przezroczystego, $\mathrm{z}$ pozoru nieosobowego. To skłonność do definiowania zjawisk niejako od podstaw, powoływania ich niemal ex nihilo do operatywnego użycia, bez nadmiernego wyczulenia na niuanse historii pojęć. Podobną funkcję uwyraźnienia własnego głosu i demonstrowania autonomiczności stanowiska pełni rozpoznawalna praktyka ${ }^{8}$ oszczędnego cytowania czy też ujawniania nawiązań do cudzych tekstów. Zasadnicze znaczenie ma również wykorzystanie swoistej siły retorycznej celowo wybieranych gatunków wypowiedzi - hasła słownikowego i encyklopedycznego, podręcznika, manifestu teoretycznego jako form gwarantujących efekt bezosobowości i niepodważalności przekazu.

Tę część książki czyta się z narastającym poczuciem niedosytu. Sławiński jest w niej doskonale izolowany od innych uczonych o podobnym podejściu - przez to niemal demonizowany, odosobniony i pozbawiony kontekstu porównawczego. Próba usytuowania własnego przedmiotu badań na tle zjawisk otaczających jest działaniem tyleż ważnym, co elementarnym i mogłoby pomóc autorce w znalezieniu odpowiedzi na pytanie, czy wskazane przez nią składniki dyskursu są tylko cechą indywidualną, w jakiej mierze charakteryzują one cały kierunek współtworzony przez wiele nieporównywalnych osobowości. Tego zróżnicowania zainteresowań badawczych, poruszanych tematyk, rodzącego też w naturalny sposób wielogłosowość polskiego strukturalizmu powojennego, zupełnie u Januszek nie ma, przez co dochodzi do zniekształcenia obrazu zarówno głównego bohatera książki, jak i jego środowiska. Próba ulokowania dyskursu Sławińskiego w kontekście praktyk wybranych badaczy tej samej szkoły powinna była stać się przedmiotem refleksji nawet w niezbyt szerokim zakresie.

W ramach stworzonego przez Januszek modelu interpretacyjnego bardziej uwidacznia się natomiast jedna $\mathrm{z}$ cech polskiego - szerzej: wschodnioeuropejskiego - strukturalizmu, którą czytelnik wszystkich omawianych tu prac uświadamia sobie z całą mocą: samorozwojowy potencjał tego nurtu, wyzwalany przezeń twórczy ferment o wartości nierzadko... autodestrukcyjnej. Fakt, że w pismach Sławińskiego znaleźć można wiele refleksji na temat tez czy pojęć subwersywnych wobec strukturalizmu (np. retoryczność języka nauki, wpływ rzeczywistego odbiorcy i świata pozatekstowego na dzieło oraz praktyki jego badania), które kierunki poststrukturalistyczne uczyniły następnie głównym przedmiotem własnego teoretyzowania, ujawnia znamienny mechanizm podejrzliwości i krytycyzmu wobec używanych narzędzi. To, co nie mieści się w ramach propozycji metodologicznych, a nawet bezpośrednio im zagraża (intertekstualność, odbiór literacki, niekonkluzywność wpisana w niektóre uprawiane przez samych strukturalistów formy wypowiedzi), zostaje mimo wszystko odsłonięte na skutek naturalnych przemieszczeń w warstwach teorii, istnieje w niej zauważone, być może celowo zaniechane lub potencjalnie gotowe do rozwinięcia. Ta refleksja powraca także w omawianych dalej tomach.

Książka Piotra Gierowskiego Struktury historii ma natomiast bohatera zbiorowego, stanowić więc może istotne uzupełnienie portretu osamotnionej indywidualności. Autor rekonstruuje bowiem polską recepcję idei Praskiego Koła Lingwistycznego - przede wszystkim w kręgu warszawskim (prestrukturalistycznym przed r. 1939 i dojrzałym, po r. 1945), ale i w przedwojennych grupach wileńskiej oraz poznańskiej. Przedstawia związki między polską i czeską nauką, akcentując wątek rodzimych, środkowoeuropejskich tradycji nowoczesnego literaturoznawstwa, kierunki wzajemnych inspiracji oraz wzbogacania teorii poprzez obustronna wymianę myśli. Jak pokazuje, recepcja strukturalistycznych idei nie była więc aktem akcesu do gotowego programu, ale miała charakter wieloaspektowej zbieżności $z$ ideami istnie- 
jącymi już w polskiej teorii literatury - prestrukturalistycznymi oraz scjentystycznymi (o różnej, także pozytywistycznej proweniencji). Odpowiadała też potrzebom badaczy niechętnych ekspansji marksizmu, działających w sytuacji powojennej restytucji życia naukowego w jego wymiarze teoriotwórczym, instytucjonalnym i dydaktycznym. Gierowski przedstawia strukturalizm jako przedsięwzięcie pokoleniowe - politycznie opozycyjne względem marksizmu, metodologicznie gwarantujące autonomiczność, integralność i uniwersalność badań, które nawiązywały jednocześnie do prądów rozwijanych na Zachodzie (we Francji czy w Stanach Zjednoczonych), a inspirowane były przecież tymi samymi ideami o strukturalistycznych korzeniach ${ }^{9}$.

W rozdziale 1, Czeskie syntezy historycznoliterackie od końca wieku XVIII do czasów pozytywizmu, Gierowski odtwarza modele historii literatury u naszych południowych sąsiadów, pokazując, które $z$ nich stanowiły propozycje przygotowujące grunt dla tendencji strukturalistycznych, a które były dla nich negatywnym punktem odniesienia. Autor pracy analizuje, jak przekonanie o konieczności rozpoznawania autonomicznych cech organizacji językowej dzieła stawało się elementem świadomości metodologicznej badaczy literatury czeskiej i jak dzięki temu kształtowała się myśl o potrzebie kompleksowej analizy budowy dzieła literackiego. Podkreśla więc te oryginalne czeskie propozycje, które zadecydowały o żywszej i efektywniejszej recepcji nowych tendencji przywiezionych w gotowej wersji do Pragi przez Romana Jakobsona.

Rozdział 2 poświęcony jest historii tworzenia się i działalności Praskiego Koła - formom jego aktywności, składowi personalnemu, pracom nad manifestem badawczym, jakim były Tezy Koła i ich pokrewieństwu z tezami Moskiewskiego Koła Lingwistycznego. Gierowski omawia chronologicznie wszelkie poczynania naukowe podejmowane przez grupe (cykle wykładów, konferencje, uczestnictwo w przedsięwzięciach międzynarodowych), charakteryzuje najważniejsze publikacje indywidualne i zespołowe. Za każdym razem zarówno skrupulatnie odnotowuje ślady współpracy uczonych czeskich i polskich, na forach międzynarodowych, jak i wskazuje kierunki i efekty kontaktów dwustronnych.

Autor, jako bohemista, w trzech pierwszych rozdziałach zainteresowany jest przede wszystkim szeroko prezentowanym kontekstem czeskim, lokalnymi tradycjami poprzedzajacymi narodziny dojrzałego strukturalizmu, dyskusjami na temat realnej wartości idei rodzimych oraz najważniejszymi propozycjami teoretycznymi w zakresie historii literatury. Omawia zespoły zadań, jakie strukturaliści prascy stawiali przed badaniami historycznoliterackimi. Tym ostatnim poświęcone są szerokie rekapitulacje - w postaci odrębnych rozdziałów - koncepcji Jana Mukařovskiego zawartej w pracy Polăkova Vznešenost př́rody (1934) oraz Felixa Vodički z jego rozprawy Literární historie, její problémy a úkoly (1942). Te części książki - w dużym stopniu będące streszczeniami obu artykułów i komentarzami do nich - dotyczą systematyzacji najważniejszych nowych kategorii badawczych wprowadzonych przez ich autorów (m.in. takich jak struktura, norma literacka, tendencje i wartość rozwojowa, proces historyczny i jego składowe), mieszczą również podsumowanie dyskusji, jakie obie propozycje wywołały w środowisku czeskim. Odnotowują także polemiki $z$ innymi koncepcjami, stanowiącymi istotny kontekst dla propozycji strukturalistycznych - tak jawi się np. znowelizowanie przez Vodičkę Ingardenowskiego pojęcia konkretyzacji. Książka zawiera więc $\mathrm{w}$ przeważającej mierze rzetelne streszczenie i systematyczny przegląd problematyki

9 To charakterystyczne przesunięcie czasowe w różnych kontekstach kulturowych, skutkujące większą samoświadomością teoretyczną drugiego pokolenia polskich strukturalistów, jest też przyczyną rozbieżności klasyfikacyjnych ich dorobku. Przykładem - przywołana już teza B ole ck i e go (op. cit.) o zbieżności problematyki podejmowanej przez najwybitniejszych reprezentantów polskiej teorii literatury w latach sześćdziesiątych i siedemdziesiątych XX wieku z kierunkami poszukiwań poststrukturalistów. 
badawczej podejmowanej przez praskich uczonych. Ponieważ przezentuje również refleksje nad tekstami nie tłumaczonymi na język polski, obfituje w długie cytaty w oryginale - co nie ułatwia lektury. Gierowski pokazuje także wewnętrzne przemiany, jakim podlegał praski strukturalizm: obie najszerzej porównywane prace dzieli 8 znamiennych lat, w tym - wojennych. Odrębna część recenzowanej książki poświęcona jest politycznym uwarunkowaniom strukturalizmu po roku 1945, przyczynom odchodzenia od studiów strukturalnych przez głównych jego przedstawicieli oraz mechanizmom zmiany pokoleniowej we wznowionej recepcji strukturalizmu (choćby na jego styku z semiotyka), omówionej przez Gierowskiego aż do początków lat dziewięćdziesiątych XX wieku. Ta najnowsza historia badań ma więc swą dodatkową wartość informacyjną dla odbiorcy zainteresowanego aktualnym statusem strukturalizmu wschodnioeuropejskiego oraz pytaniem, czy ten nurt może nadal efektywnie stymulować badania literackie, czy też ma już znaczenie przede wszystkim historyczne.

Wskazanej tu problematyce odpowiadałaby ta część tytułu pracy Gierowskiego, która dotyczy czeskiego projektu studiów historycznoliterackich. Ale w kompozycji i treści książki równoległym wątkiem są dzieje polskiej recepcji myśli strukturalistycznej i to zestawienie budzi największe poczucie wewnętrznej niespójności rozprawy, ujawniając niezdecydowanie autora co do głównego przedmiotu własnych zainteresowań. Model czeskich badań historycznoliterackich - docelowo: w swym wariancie strukturalistycznym - nie pokrywa się z dziejami recepcji strukturalizmu w Polsce, bo ta obejmowała od poczatku wiele innych działów nauki o literaturze, które autor szczegółowo i w kolejności chronologicznej omawia. Dlaczego tłem dla „czeskiego projektu dziejów literatury” miałby być odbiór strukturalizmu w przed- i powojennej Polsce lub - stawiając pytanie odwrotne - dlaczego genezę polskiego zainteresowania tym nurtem naświetlać od strony dyskusji na gruncie czeskiej estetyki? Na te pytania Gierowski nie daje odpowiedzi. Oba kręgi problemowe oczywiście ściśle się ze sobą wiążą, ale ponieważ ich zakres nie jest porównywalny, czytelnik nie może oprzeć się wrażeniu, że autor książki jeszcze na etapie jej pisania zainteresowany był dwoma odrębnymi tematami. Ich zespolenie dało rozprawę rzetelną na poziomie poszczególnych części i niespójną na poziomie koncepcji - tak naprawdę trudno jest wskazać wyrazisty problem badawczy, któremu podporządkowana byłaby całość pracy, choć rekonstruuje ona metodologiczne problemy czeskiej historii literatury i ciekawie referuje istniejace w Polsce przez kilkadziesiąt lat kierunki inspiracji nowoczesnym czeskim literaturoznawstwem. Ten brak zwartości widać też na poziomie układu materiału - między rozdziałem poświęconym Mukařovskiemu a tym o Vodičce znajduje się część dotycząca przedwojennego pokolenia prestrukturalistów polskich (m.in. działalności K. Wóycickiego, F. Siedleckiego oraz Koła Polonistów Studentów Uniwersytetu Józefa Piłsudskiego, środowiska skupionego wokół M. Kridla). Autor omawia linię rozwojową rodzimych badań nad dziełem literackim, które bezpośrednio zmierzały do koncepcji obiektywności przedmiotu studiów literaturoznawczych oraz neutralności ich metody. Przedstawia indywidualne koncepcje pokrewne przyswajanemu strukturalizmowi, odnotowuje drobiazgowo sposobności do osobistych (np. konferencyjnych) czy pośrednich (działalność przekładowa, popularyzatorska, polsko-czeskie dyskusje teoretyczne na łamach czasopism) kontaktów z uczonymi czeskimi, podsumowuje warszawsko-wileńskie przedsięwzięcia wydawnicze najlepiej dowodzące żywotnego zainteresowania zmianą modelu uprawiania dyscypliny. Wskazuje przebieg recepcji nowych idei na gruncie zarówno literaturoznawstwa, jak i językoznawstwa.

Obszerna część książki poświęcona powojennej historii odbioru strukturalizmu - w zakresie teorii i historii literatury - oraz działalności drugiego pokolenia strukturalistów na rzecz organizacji życia naukowego ma również charakter karty z dziejów nauki, o wyraźnym, chronologicznym układzie oraz informacyjnym celu. To zdecydowanie najciekawsza partia pracy - nie tyle $z$ powodu ujawniania jakichś nieznanych faktów, ile dlatego, że pokazuje immanentny potencjał twórczy rodzimego strukturalizmu, dla którego zewnętrzne wpływy były elementem wyborów metodologicznych, a nie sztywną ramą ograniczającą problematy- 
kę i stosowane procedury. Autora interesuje więc nie tylko dwubiegunowość kontaktów polsko-czeskich i wzajemne inspiracje, ale przede wszystkim paralelność rozwoju niektórych idei czy niemal symultaniczne dochodzenie do podobnych wniosków. Sukces strukturalizmu w Polsce uważa więc Gierowski za wypadkową zarówno atrakcyjności poznawczej nowej metody, jak i jej przyległości do „wspólnych inspiracji i analogicznych kierunków rozwoju” (s. 174): „adaptacja [...] propozycji czeskich w istocie przebiegała zgodnie $z$ modelem wypracowanym przez prażan w odniesieniu do historii literatury: wpływ był tu nie tyle (bądź nie tylko) przyczyną, ile przede wszystkim środkiem realizacji określonych potrzeb, jakie pojawiły się w polskim literaturoznawstwie" (s. 184).

Dlatego też rekonstrukcję wielostronnych relacji pomiędzy środowiskami rosyjskim, czeskim i polskim należy uznać za jeden z najcenniejszych aspektów pracy Gierowskiego; relacji, które - jak pokazuje autor - mogły przybierać formę absorpcji, ewaluacji, refutacji czy dyskusji. W obu kontekstach kulturowych - czeskim i polskim - Gierowski zarówno wyznacza zakres oddziaływania nowej teorii przychodzącej z zewnątrz dzięki kontaktom z uczonymi zagranicznymi (oczywista rola Jakobsona), jak i rozpoznaje liczne pokrewieństwa $z$ koncepcjami już wcześniej wypracowanymi w tych krajach samodzielnie. Wskazanie wielokulturowego podłoża tendencji strukturalistycznych i mechanizmów cyrkulacji idei w Europie Wschodniej i Środkowej tłumaczy szereg zjawisk wciąż aktualnych. Pozwala np. z większym dystansem traktować meandry czy nawroty dyskusji nad „przeciwteorią"10, „kryzysem teorii”, „opresywnością teorii” (zwłaszcza w ich wydaniu amerykańskim) ${ }^{11}$, które cechuje nierzadko zupełna nieświadomość różnic między fazami recepcji strukturalizmu, jego wcieleniami lokalnymi i wielowarstwowym narastaniem koncepcji.

Autor Struktur historii poświęca niemało miejsca sferze niezależności politycznej, jaką do pewnego stopnia zapewniały badania spod znaku strukturalizmu, i upatruje tu przyczyn jego sukcesu wśród badaczy ówczesnego młodego pokolenia ${ }^{12}$. Porównując strukturalizm z ekspansywną koncepcją marksizmu literaturoznawczego, wskazuje tak elementy wspólne (postulat naukowości czy inspiracje socjologiczne), jak i oczywiste, nieprzekraczalne różnice. Rekonstruuje wzajemny ogląd obu konkurencyjnych szkół w najważniejszych publikacjach, wystąpieniach konferencyjnych, manifestach metodologicznych. Referuje więc propozycje badawcze najaktywniejszych spośród powojennego pokolenia strukturalistów: Janusza Sławińskiego, Michała Głowińskiego, Aleksandry Okopień-Sławińskiej, Edwarda Balcerzana - odsłaniając w ich pismach zarówno świadome nawiązania do szkoły praskiej, jak i inspiracje myślą formalistyczną czy równolegle rozwijanymi na Zachodzie ideami czerpanymi z tego samego, strukturalistycznego źródła. Często zwraca uwagę na zjawiska symultanicznego pojawiania się w polskich pracach znaczących analogii do badań rozwijanych ówcześnie w zagranicznych ośrodkach. Charakteryzuje młode pokolenie i jako grupe o silnym poczuciu wspólnoty metodologicznej oraz celów poznawczych, i jako indywidualności naukowe o sprofilowanych zainteresowaniach i wyrazistych językach osobniczych, pokazując w ten sposób wewnętrzne zróżnicowanie kierunku. Zakres obserwacji Gierowskiego jest więc bardzo szeroki. Zarysowuje on tym samym panoramę powojennych przemian w literaturoznawstwie polskim, zaświadczając o dynamice i energii grupowej, jaka pozwoliła na stworzenie oraz

O niektórych wątkach $\mathrm{z}$ historii polskiego strukturalizmu w okresie przesilenia traktuje praca A. Burzyńskiej Anty-teoria literatury (Kraków 2006).

11 Godnym odnotowania, choć niezbyt reprezentatywnym przeglądem kierunków tych dyskusji jest numer tematyczny „Tekstualiów” (2013, nr 4).

12 Po latach pamięć o zwulgaryzowanej i ośmieszonej ideologizacji języka nauki pomogła ustrzec polskie literaturoznawstwo przed nadmiernie łatwą absorpcją znowelizowanej wersji marksizmu czy innych upolitycznionych języków badawczych. Zob. opinię M. Głowińskiego (Glosy do rozważań Johna M. Ellisa. „Znak” 2009, nr 10). 
realizację nowego paradygmatu naukowego. Zawsze interesuja go żywe przejawy tradycji autonomicznego i naukowego badania literaturoznawczego, ciagłość rodzimego modelu nowoczesnego literaturoznawstwa, której elementy dostrzega Gierowski zarówno w pismach najważniejszych reprezentantów dojrzałego strukturalizmu, jak i w pracach ich adwersarzy. Dużo miejsca poświęca głównym aktywnościom naukowo-organizacyjnym pokolenia i mechanizmom funkcjonowania ówczesnego życia naukowego. Omawia więc szczegółowo rolę serii wydawniczych, międzynarodowych kongresów i konferencji, umożliwiających kontakt z głównymi światowymi reprezentantami strukturalizmu, slawistyczne projekty badawcze, przedsięwzięcia dydaktyczne oraz popularyzatorskie w zakresie literaturoznawstwa, działalność przekładową i powołane instytucje naukowe.

Strukturalizm $w$ Europie Środkowej $i$ Wschodniej. Wizje i rewizje pod redakcją Danuty Ulickiej i Włodzimierza Boleckiego ma odmienny charakter niż dwie omówione wcześniej prace - jest książką zbiorową podsumowującą międzynarodową konferencję teoretycznoliteracką z 2010 roku. Zawiera 36 artykułów zgrupowanych w 3 częściach: Z prehistorii, Geografia i biografia, Dyskontynuacje. Ta inicjatywa konferencyjna i wydawnicza nawiązuje wyraźnie do chlubnych tradycji międzynarodowych przedsięwzięć różnojęzykowych środowisk strukturalistycznych, w jakie obfitowały lata sześćdziesiąte i siedemdziesiąte. Autorami zebranych tekstów są oprócz naukowców polskich również badacze z Rosji, Czech, Słowenii, a także zachodni slawiści. Publikacja - w zamierzeniu stanowiąca próbę podsumowania dorobku strukturalizmu nie tylko w Polsce - proponuje bogaty przegląd problemów historycznych i metodologicznych. Jednym $z$ wątków przewijających się przez wiele artykułów jest dążenie do odtworzenia skomplikowanej historii cyrkulacji nowych formalno-strukturalistycznych idei, uzasadnione zarówno kulturowo-geograficznym oddaleniem różnych środowisk, w jakich pojawiały się protostrukturalistyczne tendencje, jak i brzemienną w skutki mobilnością naukową wybitnych postaci uosabiających ekspansję kierunku (Jakobson, Wellek). Często więc w tomie pojawiają się refleksje na temat przyczyn zróżnicowania lokalnych wersji strukturalizmu. Temu zagadnieniu poświęcone są w całości teksty Karola Sauerlanda Strukturalizm - antidotum na Geisteswissenschaften, Alenki Koron Oddziaływanie europejskiego strukturalizmu na słoweńskie badania literackie w latach 1960-2000: lokalna recepcja i najważniejsze osiagnięcia, Natalii Malutiny Ukrainski formalizm lat dwudziestych XX wieku. $Z$ tymi artykułami korespondują studia na temat historii idei ważnych, a wcześniejszych od strukturalizmu: Bogusław Żyłko przedstawił tu refleksję nad metajęzykiem i dążeniem do wypracowania modelu ścisłości/naukowości literaturoznawstwa czy szerzej - humanistyki (Idea „ścisłego literaturoznawstwa” $w$ rosyjskiej nauce o literaturze XX wieku), a Maciej Adamski zanalizował stosunek Kazimierza Wóycickiego do tradycji pozytywistycznej, rekonstruując postawę względem scjentyzmu i psychologizmu ujawniającą się w jego pracach teoretycznych (Pozytywizm Kazimierza Dominika Wóycickiego).

Nie zabrakło także omówień zjawisk dla strukturalizmu nieoczywistych bądź nie do końca zagospodarowanych teoretycznie, lecz podskórnie nurtujących i powracających na różnych poziomach refleksji. Tak więc Piotr Bogalecki (Mimowolna mimologia? Mit kratylejski a polski strukturalizm) przedstawił status idei odpowiedniości słowa i rzeczy (przybierającej formę m.in. symbolizmu dźwiękowego, ikoniczności, odmian naśladowania cudzej mowy).

Inne przyczyny wewnętrznego zróżnicowania strukturalizmu w różnych jego fazach historycznych wskazują te artykuły, które rozpoznają zależności między autorskimi koncepcjami badawczymi a mechanizmami społeczno-kulturowymi i instytucjonalnymi warunkującymi ich recepcję. Do tego rodzaju tekstów należą obszerne rozprawy poświęcone indywidualnościom nierzadko zapomnianym; tak jest w przypadku artykułu Craiga Brandista Paleontologia fabuły i metafory Izraila Grigoriewicza Frank-Kamienieckiego. Podobnie w artykule pod znaczącym tytułem Innowacja i regresja. Zainteresowania teoretyczne Gustawa 
Szpeta $w$ latach dwudziestych Galin Tihanov pisze o uczonym dalekim od przynależności do kręgu formalistów, ale wywierającym bardzo ważny, niekiedy ambiwalentny, wpływ na niektóre ich frakcje. Obaj autorzy wskazują na istnienie w pracach swoich bohaterów pokrewieństw między ich wybranymi tezami a kształtującym się dopiero nowym modelem badań, akcentując również antecedencje teorii o wiele późniejszych, z dojrzałej fazy strukturalizmu lub szkół zeń się wywodzących. Igor Pilszczikow natomiast podsumowuje zbieżności, ale i znamienne różnice między ośrodkami badań formalnych petersburskim i moskiewskim, charakteryzując jednocześnie indywidualne propozycje najwybitniejszych przedstawicieli obu kręgów (Dziedzictwo rosyjskiej szkoły formalnej. OPOJAZ i Moskiewskie Koło Lingwistyczne a wspótczesna filologia).

O kolejnym zagadnieniu z prehistorii strukturalizmu traktuje artykuł Danuty Ulickiej (Habent sua fata libelli. 〈O pierwszym przekładzie „Kursu językoznawstwa ogólnego”), poświęcony potencjalnemu wpływowi, jaki mogło wywrzeć pierwsze gotowe, komentowane przez współczesnych autorowi, acz nie opublikowane ostatecznie, rosyjskie tłumaczenie wykładów Ferdinanda de Saussure'a. W dziejach jego powstania, w semantyce zaproponowanej terminologii i założeniach epistemologicznych oraz w toku dyskusji nad tymi rozstrzygnięciami dostrzega Ulicka historię narodzin i ścierania się różnych koncepcji, które zadecydowały o późniejszym kształcie literaturoznawstwa. Rozpoznaje także, nie zrealizowany wówczas, sprawczy potencjał przekładu noszącego w sobie ogólne wytyczne dla (s)tworzonej po dziesięcioleciach antropologii słowa. Zadziwiające, że w omawianym tomie tekst Ulickiej to w istocie jedyny artykuł bezpośrednio dotykający zagadnienia konstytuującego najnowszą falę refleksji nad strukturalizmem i jego międzykulturową cyrkulacją: kwestii przekładu i jego teoriotwórczej (kulturotwórczej) funkcji ${ }^{13}$. Choć jest to autonomiczny przedmiot badawczy autorów zamieszczonych tu prac (przede wszystkim E. Balcerzana, D. Ulickiej, T. Brzostowskiej-Tereszkiewicz), w omawianym tomie istnieje on jedynie między wierszami i nie doczekał się syntetycznego naświetlenia na jego potrzeby.

Dwa artykuły zostały poświęcone formom wypowiedzi naukowej. Nina Władimirowna Braginska zrekonstruowała dotychczas pomijany przez badaczy innowacyjny potencjał komentarza - w jego bogatej i różnokulturowej historii (Komentarz - próba definicji). Tamara Brzostowska-Tereszkiewicz w studium o literaturoznawczej etiudzie jako popularnym gatunku pisarstwa literaturoznawczego pierwszych dekad XX wieku - pokazała genologiczną otwartość i antysystemowość jako wykładnik immanentnie istniejącej w prestrukturalizmie samoświadomości teoretycznej. Zakwestionowała tym samym utożsamienie takich postaw, jak metarefleksja nad figuratywnościa języka nauki czy antydogmatyczność, z klimatem intelektualnym postmodernizmu.

W kręgu zainteresowań indywidualnymi dokonaniami reprezentantów różnych okresów badań formalno-strukturalnych pozostają szkice Mirosława Skarżyńskiego Nowoczesne państwo i społeczeństwo w poglądach Jana Baudouina de Courtenay, Ondřja Sládka René Wellek i praska szkoła strukturalna oraz Jany Hoffmannovej Miroslav Červenka - badacz strukturalista, poeta, diarysta. Zadziwia jednak w tym miejscu brak osobnych charakterystyk osiagnięć naukowych polskich reprezentantów szczytowej fazy strukturalizmu. Portret zbiorowy pokolenia można odtworzyć $z$ szeregu tekstów zdających sprawę $z$ form jego instytucjonalno-badawczej aktywności, ale (wypada żałować) żaden $z$ odrębnych artykułów nie doprecyzowuje tego wizerunku poprzez zaakcentowania oryginalności naukowej poszczegól-

13 To zagadnienie centralne dla tzw. zwrotu archiwistycznego oraz badań nad poetyka przekładu naukowego. Zob. Ulicka, op. cit. - T. Brzostowska-Tereszkiewicz: Poetyka przekładu literaturoznawczego. W zb.: Od tematu do rematu; Modernist Translation. An Eastern European Perspective. Models, Semantics, Functions. Frankfurt am Main - Wien 2016. 
nych badaczy czy też poprzez próbę hasłowego ${ }^{14}$ porównania ich dorobku lub wskazania wyjątkowości w obrębie strukturalizmu w naszej części Europy. A tego w ramach omawianej publikacji można było oczekiwać. Idealnym dopełnieniem geograficzno-biograficznej części tomu stałyby się więc artykuły realizujące w pigułce zamysł książki Januszek o Sławińskim lub fragmentów pracy Gierowskiego o koncepcjach różnych naukowców spod znaku strukturalizmu. Jeden $z$ aspektów dorobku Sławińskiego uczynił przedmiotem rozważań - w szkicu Janusza Sławińskiego idea podmiotu (w szczególności: lirycznego) - Marian Płachecki, który w stwierdzeniach tego badacza na temat podmiotu literackiego dopatrywał sie przemyślnej taktyki odpersonalizowania aktu komunikacji w warunkach zniesionej wolności słowa. Dwa artykuły: Seweryny Wysłouch Strukturalizm i semiotyka $w$ pracach Jerzego Ziomka oraz Jerzego Madejskiego Archiwum badacza literatury jako problem teoretycznoliteracki (o zasobach $\mathrm{H}$. Markiewicza), dotyczą metodologicznych problemów studiowania spuścizny uczonych, których prace były istotnym kontekstem dla strukturalistów i powstawały w bezpośredniej styczności $z$ ich propozycjami.

Ze zgromadzonych w książce publikacji wyłania się obraz strukturalizmu przede wszystkim jako przedsięwzięcia skonsolidowanego środowiska naukowego, zespolonego podobnymi celami badawczymi i - co warte podkreślenia również z dzisiejszej perspektywy - doskonale przygotowanego do dynamicznej kooperacji naukowej, także na gruncie międzynarodowym. Ten bardzo nowoczesny rys uprawiania nauki (negujący izolacjonistyczne tendencje nieobce humanistom czy niekiedy mylnie utożsamiane $\mathrm{z}$ istotą pracy humanisty $\mathrm{w}$ ogóle) podkreślają autorki dwóch artykułów - Teresa Dobrzyńska (Czesi w Warszawie. Inspiracje oraz obszary wspólnych badań $w$ zakresie stylistyki, wersologii $i$ teorii tekstu) i Lucylla Pszczołowska (Stowiańska metryka porównawcza. Ewolucja celów i metod badawczych). Ten obraz strukturalizmu pozostaje $\mathrm{w}$ wyraźnej sprzeczności $\mathrm{z}$ indywidualistycznie przerysowanym wizerunkiem, jaki nakreśliła w swej książce Januszek ${ }^{15}$. Co ciekawe, tę grupową energię Adam F. Kola dostrzega także w przedwojennej fazie kształtowania się kierunku (Powstanie i rozwój szkoły badawczej Manfreda Kridla. Rola aktorów poza-ludzkich), analizując metody działania środowiska wileńskiego - ześrodkowanego wokół założeń metodologicznych i epistemologicznych, nie odwołującego się do „wyznawczo-mistrzowskiej” relacji z liderem zespołu. Aspektem instytucjonalno-dydaktycznym strukturalizmu (i jego aktualnymi do dziś konsekwencjami) zajął się natomiast Maciej Gorczyński (Strukturalizm, uniwersytet, ksztatcenie).

Odrębna część tomu prezentuje podsumowania i oceny spuścizny strukturalizmu w różnych dziedzinach nauki o literaturze oraz rozpoznania co do aktualności niektórych pojęć z jego słownika. Na gruncie stylistyki taką wieloaspektową rekonstrukcje przeprowadziła Bożena Witosz. Pokazując zależności między badaniami nad kategorią stylu funkcjonalnego spod znaku szkoły praskiej a aktualnie rozwijanymi studiami nad kategorią dyskursu, autorka zwraca uwage na zagrożenia płynące ze zbyt łatwej nowelizacji siatki pojęciowej, nie popartej autorefleksją metodologiczną i namysłem krytycznym nad ewolucją pojęć. O nowych czeskich badaniach nad stylami rozwijających propozycje prażan pisała także Světla Čmejrková (Czeskie strukturalistyczne koncepcje stylu i ich współczesna recepcja). Teresa Dobrzyńska omówiła lingwistyczne koncepcje metafory (Metafora $w$ dyskusjach warszawskich $z$ lat

14 Zob. E. M o ż ej k o, Structuralism, Polish. Hasło w: Encyclopedia of Contemporary Literary Theory. Ed. I. Makaryk. Toronto-London 1993.

15 Znamienne, że żaden $z$ tekstów traktujących o zespołowej pracy podejmowanej przez różne kręgi i ośrodki strukturalistyczne nie koresponduje ze sposobem opisu i interpretacji tego wątku, przedstawionym wcześniej przez D. Lewińskiego w książce Strukturalistyczna wyobraźnia metateoretyczna: o procesach paradygmatyzacji $w$ polskiej nauce o literaturze po 1958 roku (Kraków 2004). 
siedemdziesiatych XX wieku, czyli ku lingwistycznej teorii tropu). Anna Łebkowska wskazała natomiast - w pracy Polski wariant strukturalizmu a współczesny dyskurs literaturoznawczy - szereg pojęć i teorii będących oryginalnym dorobkiem polskiej wersji strukturalizmu, które zachowują przydatność w aktualnie rozwijanych badaniach nad odbiorem literackim (np. w ich feministycznej wersji), w licznych projektach literackiej i literaturoznawczej antropologii oraz narratologii wielomedialnej. To więc kolejny tekst zwracający uwagę na koncepcyjny zaczyn tkwiący w strukturalizmie, na pokłady transformacyjnej energii uwalnianej przez lata. Zjawisku przeciwstawnemu - zaniechaniom i „niedokończonym projektom” zawartym w koncepcjach formalno-strukturalistycznych - przyjrzała się natomiast Magdalena Danielewiczowa (Dziedzictwo Ferdynanda de Saussure'a w jednym z nurtów polskiej semantyki), skupiając się na konsekwencjach niewystarczająco rozwiniętej w językoznawstwie refleksji nad mechanizmami mownymi i zasadami delimitacji jednostek konkretnych. Problematykę językoznawstwa reprezentuje również tekst Jana Kordysa na temat metod analizy etymologiczno-semantycznej stworzonej na gruncie indoeuropeistyki przez Władimira Nikołajewicza Toporowa oraz jej usytuowania wobec różnych obszarów dziedzictwa strukturalistycznego. Wybranymi zagadnieniami z zakresu stylistyki zajęła się także Zofia Mitosek (Mowa pozornie zależna, ironia i ideologia), analizując potencjalne związki między ironią a mową pozornie zależną oraz światopoglądowym wymiarem tego powinowactwa - zarówno w praktykach artystycznych, jak i w strukturalistycznej refleksji (zapoczątkowanej w Polsce przez D. Hopensztanda) nad metakomunikacją ironiczną.

Tekst Małgorzaty Gorczyńskiej (Dyskusja, której nie było. O pewnym epizodzie z dziejów polskiej i czeskiej wersologii) porusza natomiast ciekawe zagadnienie braku merytorycznej debaty pomiędzy reprezentantami różnych, konkurujących ze sobą, teorii wersologicznych - a więc w łonie dyscypliny niegdyś uprzywilejowanej w obrębie strukturalizmu i wyraźnie nadającej kierunek jego rozwojowi. Różnice między założeniami zespołu Słowiańskiej Metryki Porównawczej a kontrpropozycją wersologiczną Adama Kulawika rozpatruje Gorczyńska także jako aspekt zjawiska narastania strukturalistycznej ortodoksji, a więc analizuje mechanizmy historyczne sterujące fazami rozwojowymi kierunków badawczych. Do współczesnego stanu badań wersologicznych nawiązuje również tekst Adama Dziadka Wersologia polska - kontr(o)wersje, dotyczacy koncepcji rytmu ${ }^{16}$, jedyny w istocie artykuł z tomu proponujący alternatywną względem koncepcji strukturalistów refleksję nad żywo interesującymi ich kategoriami. Stąd przemożne wrażenie czytelnicze, że tom poświęcony „wizjom i rewizjom" strukturalizmu jest jednak bardzo mało rewizjonistyczny, a sam kierunek jakoby nie wywoływał większych kontrowersji, gorętszych dyskusji, fundamentalnych sporów. O ich wielowątkowości, zróżnicowanym emocjonalnym natężeniu i pokoleniowej stratyfikacji zaświadcza jedynie wstępny artykuł Edwarda Balcerzana Oświetlenia strukturalizmu - błyskotliwa autorska przymiarka do skonstruowania ogólnego modelu recepcji strukturalizmu w środowiskach zarówno jego reprezentantów, jak i polemistów, adwersarzy czy likwidatorów.

W przypadku kilku zagadnień omawianych w tomie widoczny staje się fakt, że brakuje w Polsce (i nie tylko) żywszej potrzeby podjęcia tych kierunków badań, których narodziny można wiązać także $z$ inspiracją formalno-strukturalistyczną. Najwyraźniejszy przykład stanowi tu narratologia postklasyczna ${ }^{17}$, pominięta w zaprezentowanych $\mathrm{w}$ tomie analizach

16 Autor konsekwentnie rozwija swą teorię rytmu i powiązanego $\mathrm{z}$ nim anagramu fonetycznego właśnie jako alternatywną dla zakorzenionych w strukturalizmie ujęć, a jednak bezpośrednio inspirowaną mniej znanymi koncepcjami de Saussure'a. Zob. A. D z i a d e k, Rytm i podmiot w liryce Jarosława Iwaszkiewicza i Aleksandra Wata. Katowice 1999.

17 Zróżnicowaniu narratologii postklasycznej oraz twórczym przekształceniom czy kontynuacjom strukturalistycznych badań nad narracja poświęciłam fragment książki Poetyka intersubiektywności. Kognitywistyczna teoria narracji a proza XX wieku (Torun 2012, s. 65-79). 
spuścizny strukturalizmu w różnych obszarach literaturoznawczych ${ }^{18}$. Bohumil Fořt (Szkoła praska a nowoczesna teoria narracji) skupił się wyłącznie na historii siatki pojęciowej wywiedzionej z pism narratologicznych szkoły praskiej. Podobnie zaskakuje brak odniesienia do dynamicznie rozwijanych empirycznych wersji badań nad odbiorem literackim - w całym ich bogactwie metodologicznym. O dostrzegalnych zbieżnościach między strukturalizmem a np. dzisiejszymi badaniami kognitywistycznymi wspominaja przecież nawet naukowcy, którzy od początku swej działalności utożsamiają się z tym pierwszym kierunkiem ${ }^{19}$.

Rolf Fieguth (w tekście Wyglady Ingardena jako prowokacja ikonofobii strukturalizmu. O reżyserii światła słonecznego $w$ „Quidamie” Norwida) zajmuje się wyparciem poza obręb teorii strukturalizmu „aspektów zmysłowości wyobrażeniowej”. Sensualizm czytania inne kierunki badawcze uczyniły jednym $z$ najsilniejszych środków literackiego oddziaływania na czytelnika, nie dewaluując jego potrzeby, by czerpać z lektury zmysłową przyjemność. Fieguth wskazuje tylko na linię psychoanalitycznych badań nad odbiorem jako na marginalizowaną ostoję steoretyzowania czytelniczego doświadczenia zmysłowego, zabarwiającego konkretyzację. Tymczasem to tendencja wyraźnie zarysowana w studiach nad odbiorem literackim z lat dziewięćdziesiątych, zarówno nawiązująca do badań nad poetyką utworu literackiego, jak i inspirowana przemyśleniami na temat jego uwarunkowań poznawczych ${ }^{20}$. Trudno nie zauważyć, że istotnym i rodzimym kontekstem (jakkolwiek operacjonalizowanym) dla tych badań są propozycje polskiej szkoły komunikacji literackiej (Sławiński, Okopień-Sławińska) oraz poetyki odbioru (Głowiński, Balcerzan).

Omawiany tom w zasadzie nie dokumentuje (wciąż oczekiwanej przecież) historii sporów ze strukturalizmem ani jego stanowisk wobec tego, co tworzyło dlań potencjalną alternatywę: czy to we wstępnym okresie prezentacji nowinek teoretycznych (z początku lat dziewięćdziesiątych, w pierwszym roczniku „Tekstów Drugich”), czy to w czasach coraz żywszego rozkwitu odmiennych propozycji. Obraz wygasania strukturalizmu jest w procedurach badawczych pokolenia ostatniego 20-lecia nader statyczny, by nie powiedzieć wręcz - myląco uładzony. Jakby nie miały miejsca mniej lub bardziej gorace starcia na temat wolności i granic interpretacji, wspólnot ją uprawiających, roli odbiorcy (a także odbiorczyni!) i potencjalnych ograniczeń praw czytelników do dysponowania znaczeniami tekstu. Żaden $z$ autorów nie podjął wątku historycznie granicznych punktów strukturalizmu i jego strategii zaczepno-obronnych wobec już dostrzeganych „postrachów” (by posłużyć się określeniem Sławińskiego) ${ }^{21}$. Może to oznaczać tylko jedno - że na summę dokonań tego kierunku nadal, $\mathrm{z}$ różnych względów, za wcześnie.

\author{
Abstract \\ MAGDALENA REMBOWSKA-PŁUCIENNIK \\ Institute of Literary Research of the Polish Academy of Sciences, Warsaw
}

\title{
STRUCTURALIST DISPERSIONS
}

The review discusses three books on the newest debates on the legacy of Polish and Eastern European structuralism. The papers, taking up both its history, assumptions of the method, and its most outstanding representatives, are linked by one thesis, namely a conviction about a still inspiring (and still rediscovered) heterogeneity of this literary research mode of analysis.

Kwestii narratologii w perspektywie nowych mediów dotyka w swym artykule jedynie A. Łebkowska.

19 Zob. J. Ś w i ę c h, Strukturalizm na cenzurowanym. W: Nowoczesność. Szkice o literaturze polskiej. Warszawa 2006, s. 339.

20 Zob. E. E s r o c k, The Reader's Eye. Visual Imaging as Reader Response. Baltimore 1994.

21 J. Sławiński, Trzy postrachy. „Teksty” 1975, nr 3. 